\title{
Optimization of Benzoguanamine doped PVDF/KI/I2 Solid Polymer Electrolytes for Dye-Sensitized Solar Cell Applications
}

Kannadhasan Sundaramoorthy ( $\sim$ skannadhasanssn@gmail.com )

Sri Sivasubramaniya Nadar College of Engineering https://orcid.org/0000-0003-4132-2375

Muthu Senthil Pandian

Sri SivaSubramaniya Nadar College of Engineering

P. Ramasamy

Sri SivaSubramaniya Nadar College of Engineering

\section{Research Article}

Keywords: Dye sensitized solar cell, Crystallinity, Benzoguanamine, Thin films, Polymer electrolytes, Nanocrystalline materials.

Posted Date: March 23rd, 2021

DOI: https://doi.org/10.21203/rs.3.rs-322818/v1

License: (9) This work is licensed under a Creative Commons Attribution 4.0 International License. Read Full License 


\section{Abstract}

Benzoguanamine doped $0 \%, 10 \%, 20 \%, 30 \%, 40 \%$ and $50 \% \mathrm{PVDF} / \mathrm{KI} / \mathrm{I}_{2}$ polymer electrolytes were prepared by solution casting technique. The crystallinity, surface morphology, ionic conductivity and photovoltaic performance of polymer electrolytes were analyzed. The PXRD studies have confirmed the decreased and increased crystallinity of benzoguanamine doped polymer electrolytes. The surface morphology of polymer electrolytes is discussed using SEM analysis. From the AC-impedance analysis, ionic conductivity of benzoguanamine doped $0 \%, 10 \%, 20 \%, 30 \%, 40 \%$ and $50 \% \mathrm{PVDF} / \mathrm{KI} / \mathrm{I}_{2}$ polymer electrolytes were calculated as $5.57 \times 10^{-6} \mathrm{Scm}^{-1}, 1.05 \times 10^{-5} \mathrm{Scm}^{-1}, 5.95 \times 10^{-5} \mathrm{Scm}^{-1}, 3.09 \times 10^{-5}$ $\mathrm{Scm}^{-1}, 1.56 \times 10^{-5} \mathrm{Scm}^{-1}$ and $1.48 \times 10^{-5} \mathrm{Scm}^{-1}$, respectively. The photovoltaic performance of benzoguanamine doped $0 \%, 10 \%, 20 \%, 30 \%, 40 \%$ and $50 \% \mathrm{PVDF} / \mathrm{KI} / \mathrm{I}_{2}$ polymer electrolytes based DSSCs have achieved $1.5 \%, 1.9 \%, 2.8 \%, 2.5 \%, 2.3 \%$ and $2.1 \%$ power conversion efficiency, respectively.

\section{Introduction}

Ion diffusion and ionic conductivity of the polymer electrolytes are lower than the liquid electrolytes. However, the research is going on to develop a novel polymer electrolyte with higher ion diffusion and ionic conductivity with good stability. Higher ionic conductivity occurs by the creation of an amorphous phase or suppression of the crystallinity of polymer electrolytes. The many efforts are taken to reducing the crystallinity or creating an amorphous phase. This can be achieved by various techniques. They are polymer blending, co-polymerization, addition of nanofillers and the incorporation of organic plasticizers [1-6]. The addition of organic plasticizers decreases both the crystallinity and polymer-polymer chain interactions in polymer electrolytes. It will enhance the segmental motion of the polymer backbone and generate free volume. The ions can easily migrate via the free volume; it will improve ionic conductivity of polymer electrolytes and the performance of DSSCs.

The researchers have fabricated DSSCs with the organic plasticizer doped polymer electrolytes and achieved considerable power conversion efficiency [7-8].

In this present work, one of the organic plasticizer benzoguanamine compound is chosen to prepare the polymer electrolytes with $\mathrm{PVDF} / \mathrm{KI} / \mathrm{I}_{2}$. The addition of the benzoguanamine compound in the polymer matrix is one of the routes to create the amorphous phase or decreased crystallinity of polymer electrolytes. This will increase the ionic conductivity of polymer electrolytes. The benzoguanamine compound consists of nitrogen atoms, which will form complex with $\mathrm{I}_{2}$. This complex formation avoids the sublimation of iodine and it will increase the lifetime of the DSSC [9]. The benzoguanamine compound is of low cost and it is also a new material for the electrolyte preparation in DSSC.

\section{Materials}

Titanium dioxide $\left(\mathrm{TiO}_{2}\right)$ nanoparticles synthesized by Sol-Gel technique [10]. Fluorine doped tin oxide (FTO) substrates, N719 dye (cis-diisothocyanato-bis (2,2'-bipyridyl-4,4'-dicarboxylato) ruthenium (II) 
bis(tetrabutylammonium)), and platinum catalyst solution (platisol) were used as purchased from Solaronix, Switzerland. Ethanol and N,N-dimethylformamide (DMF) were used as purchased from Merck. 2-amino-4,6-dimethoxypyrimidine was used as obtained from Alfa Aesar. PVDF (MW 275,000 g/mol), KI and $\mathrm{I}_{2}$ were used as purchased from Sigma-Aldrich.

\section{Preparation of Benzoguanamine-doped PVDF/KI/ ${ }_{2}$ Electrolyte Films}

The benzoguanamine-doped PVDF/KI $/ \mathrm{I}_{2}$ electrolytes were prepared by dissolving PVDF $(0.3 \mathrm{~g}), \mathrm{KI}(0.03$ g), $\mathrm{I}_{2}(0.006 \mathrm{~g})$ and benzoguanamine (different weight percentages of $0 \%, 10 \%, 20 \%, 30 \%, 40 \%$ and $50 \%$ with respect to $\mathrm{KI})$ in DMF $(20 \mathrm{~mL})$ under continuous stirring at $80^{\circ} \mathrm{C}$ until the homogeneous polymer electrolyte solutions were obtained. The obtained homogeneous polymer electrolyte solutions were poured into glass petri dishes. The DMF solvent was removed by using a vacuum oven at $60^{\circ} \mathrm{C}$ for $12 \mathrm{hrs}$.

\section{Fabrication of Dye Sensitized Solar Cell}

The solvents (acetone, ethanol and Millipore water) were used to clean the fluorine doped tin oxide (FTO) substrates. The cleaned FTO substrates were treated on $\mathrm{TiCl}_{4}$ treatment (FTO immersed with ice (50 ml), Millipore water $(50 \mathrm{ml})$ and $\mathrm{TiCl}_{4}(2 \mathrm{ml})$ at $70^{\circ} \mathrm{C}$ for $\left.30 \mathrm{~min}\right)$ after that washed by ethanol and then sintered at $500^{\circ} \mathrm{C}$ for $30 \mathrm{~min}$. $\mathrm{TiO}_{2}$ paste $\left(\mathrm{TiO}_{2}\right.$ paste was made by adding binder materials such as 2propanol and triton $\mathrm{X}-100$ with $\mathrm{TiO}_{2}$ nanoparticles) was deposited on the $\mathrm{FTO}$ and then sintered at $500^{\circ} \mathrm{C}$ for $1 \mathrm{~h}$. $\mathrm{TiCl}_{4}$ treatment is done, followed by sintering at $500^{\circ} \mathrm{C}$ for $30 \mathrm{~min}$. The photoanode is immersed in N719 dye solution ( $0.05 \mathrm{mM}$ concentration, absolute ethanol is used as solvent) for $24 \mathrm{~h}$. After that, working electrodes were obtained. The platisol was deposited (doctor blading technique) on FTO substrate and then sintered at $400^{\circ} \mathrm{C}$ for $30 \mathrm{~min}$. After that, counter electrode was obtained. The semisolid benzoguanamine doped $\mathrm{PVDF} / \mathrm{KI} / \mathrm{I}_{2}$ polymer electrolyte was dropped onto working electrode. It was kept for a few minutes for solvent evaporation and the counter electrode was placed over it. The sandwiched cell was put together with binding clips. The active area of DSSC is $0.5 \mathrm{~cm} \times 0.5 \mathrm{~cm}$. The photovoltaic $(\mathrm{J}-\mathrm{V})$ measurements are monitored at air mass (AM) 1.5 illumination using Keithley source meter with a light source of $150 \mathrm{~W}$ Xenon arc lamp (Science Tech, Canada) at $100 \mathrm{~mW} / \mathrm{cm}^{2}$.

\section{Characterization Techniques}

The powder X-ray diffraction pattern was recorded using Bruker advance D8 powder X-ray diffractometer with CuKa radiation $(\lambda=1.54 \AA$ ). The AC-impedance analysis was taken using an electrochemical workstation (Ametek, V3-500). The scanning electron microscopy images were taken using JEOL 6390 model. The photovoltaic measurements were recorded at air mass (AM) 1.5 illumination using Keithley source meter with a light source of $150 \mathrm{~W}$ Xenon arc lamp (Science Tech, Canada) at $100 \mathrm{~mW} \mathrm{~cm}^{-2}$.

\section{Results And Discussion}

\section{Powder X-ray Diffraction Analysis}


Figure 1.1 shows the powder X-ray diffraction (PXRD) spectra of benzoguanamine $(0 \%, 10 \%, 20 \%, 30 \%$, 40\% and 50\%) doped PVDF/KI/I 2 electrolyte films. The benzoguanamine (0\%, 10\%, 20\%, 30\%, 40\% and $50 \%$ ) doped PVDF/KI/I 2 electrolyte films exhibited X-ray diffraction peaks at $2 \theta=20^{\circ}, 22^{\circ}, 25^{\circ}, 36^{\circ}, 42^{\circ}$ and $44^{\circ}$. The peak's intensity of $0 \%$ benzoguanamine doped $\mathrm{PVDF} / \mathrm{KI} / \mathrm{I}_{2}$ electrolyte film is higher than the benzoguanamine (10\%, 20\%, 30\%, 40\% and 50\%) doped PVDF/KI/I 2 electrolyte films. These results confirmed the decreased crystallinity of benzoguanamine (10\%, 20\%, 30\%, 40\% and 50\%) doped $\mathrm{PVDF} / \mathrm{KI} / \mathrm{I}_{2}$ electrolyte films. When the benzoguanamine is added, the intensity of peaks was found to be gradually decreased up to $20 \%$. This confirmed the decreased crystallinity of benzoguanamine ( $10 \%$ and $20 \%$ ) doped PVDF/KI/I 2 electrolyte films. But when the amount of benzoguanamine was increased further, the intensity of peaks was gradually increased. This confirmed the increased crystallinity of benzoguanamine $(30 \%, 40 \%$ and $50 \%)$ doped PVDF/KI/I 2 electrolyte films. The results obtained from the PXRD measurements confirm the lowest crystallinity of $20 \%$ benzoguanamine doped PVDF/KI/I 2 electrolyte film than the other benzoguanamine (0\%, 10\%, 30\%, 40\% and 50\%) doped PVDF/KI/I 2 electrolyte films.

\section{Ionic Conductivity Studies}

The AC-impedance spectra of prepared benzoguanamine (0\%, 10\%, 20\%, 30\%, 40\% and 50\%) doped $\mathrm{PVDF} / \mathrm{KI} / \mathrm{I}_{2}$ electrolyte films are presented in Fig. 1.2. The ionic conductivity of benzoguanamine doped $\mathrm{PVDF} / \mathrm{KI} / \mathrm{I}_{2}$ electrolyte films was measured from Fig. 1.2, and the obtained values are listed in Table 1.1. The ionic conductivity of benzoguanamine $(0 \%, 10 \%, 20 \%, 30 \%, 40 \%$ and $50 \%)$ doped PVDF $/ \mathrm{KI} / \mathrm{I}_{2}$ electrolyte films are $5.57 \times 10^{-6} \mathrm{Scm}^{-1}, 1.05 \times 10^{-5} \mathrm{Scm}^{-1}, 5.95 \times 10^{-5} \mathrm{Scm}^{-1}, 3.09 \times 10^{-5} \mathrm{Scm}^{-1}, 1.56$ $\times 10^{-5} \mathrm{Scm}^{-1}$ and $1.48 \times 10^{-5} \mathrm{Scm}^{-1}$, respectively. The benzoguanamine (10\%, 20\%, 30\%, 40\% and 50\%) doped PVDF/KI/I 2 electrolyte films have higher ionic conductivity than the $0 \%$ benzoguanamine doped $\mathrm{PVDF} / \mathrm{KI} / \mathrm{I}_{2}$ electrolyte film. The reason for the observed trend is the addition of benzoguanamine. The ionic conductivity was increased with the addition of benzoguanamine up to $20 \%$. This may be due to the increased number of mobile charge carriers and chain mobility of polymer electrolytes [11, 12]. After 20\%, the ionic conductivity of benzoguanamine (30\%, $40 \%$ and $50 \%)$ doped electrolyte films was found to be decreased. This is due to the taking up of some free volume, the rapid increase in viscosity and some benzoguanamine may not be dissociated in polymer electrolytes. So, it causes the interrupted mobility of the charge carriers and thereby reduces the ionic conductivity [11]. The highest ionic conductivity was obtained for $20 \%$ benzoguanamine doped PVDF/KI/I 2 electrolyte film. This highest ionic conductivity is responsible for the highest power conversion efficiency of DSSC. Figure 1.3 represents the plot of ionic conductivity variations of benzoguanamine doped PVDF/KI/I 2 electrolyte films. 
Table 1.1

Conductivity of benzoguanamine (a) $0 \%$, (b) $10 \%$, (c) $20 \%$, (d) $30 \%$,

(e) $40 \%$ and (f) $50 \%$ doped PVDF/KI/I 2 electrolyte films

\begin{tabular}{|lll|}
\hline Electrolyte & Benzoguanamine (\%) & Ionic Conductivity $\left(\mathrm{Scm}^{-1}\right)$ \\
\hline a & 0 & $5.57 \times 10^{-6}$ \\
\hline b & 10 & $1.05 \times 10^{-5}$ \\
\hline c & 20 & $5.95 \times 10^{-5}$ \\
\hline d & 30 & $3.09 \times 10^{-5}$ \\
\hline e & 40 & $1.56 \times 10^{-5}$ \\
\hline f & 50 & $1.48 \times 10^{-5}$ \\
\hline
\end{tabular}

\section{Scanning Electron Microscopy Analysis}

The surface morphology of benzoguanamine $(0 \%, 10 \%, 20 \%, 30 \%, 40 \%$ and $50 \%)$ doped $\mathrm{PVDF} / \mathrm{KI} / \mathrm{I}_{2}$ electrolyte films is characterized by scanning electron microscopy (SEM) analysis. The SEM images of benzoguanamine $(0 \%, 10 \%, 20 \%, 30 \%, 40 \%$ and $50 \%)$ doped $\mathrm{PVDF} / \mathrm{KI} / \mathrm{I}_{2}$ electrolyte films are presented in Fig. 1.4. The surface morphology of benzoguanamine doped $\mathrm{PVDF} / \mathrm{KI} / \mathrm{I}_{2}$ electrolyte films has shown the spherical particles with voids. The $0 \%$ benzoguanamine doped $\mathrm{PVDF} / \mathrm{KI} / \mathrm{I}_{2}$ electrolyte film has the largest size spherical particles voids than the benzoguanamine $(10 \%, 20 \%, 30 \%, 40 \%$ and $50 \%)$ doped $\mathrm{PVDF} / \mathrm{KI} / \mathrm{I}_{2}$ electrolyte films. The spherical particle size was gradually decreased with voids up to $20 \%$ of benzoguanamine doped PVDF/KI/I 2 electrolyte films. In the $30 \%, 40 \%$ and $50 \%$ of benzoguanamine doped $\mathrm{PVDF} / \mathrm{KI} / \mathrm{I}_{2}$ electrolyte films, the spherical particle size was gradually increased with voids. The $20 \%$ benzoguanamine doped $\mathrm{PVDF} / \mathrm{KI} / \mathrm{I}_{2}$ electrolyte film has shown the smallest spherical particles with voids. The benzoguanamine contributes a notable effect in the benzoguanamine doped $\mathrm{PVDF} / \mathrm{KI} / \mathrm{I}_{2}$ electrolyte films $[13,14]$.

\section{Photovoltaic Measurements}

The DSSCs were fabricated with the prepared benzoguanamine $(0 \%, 10 \%, 20 \%, 30 \%, 40 \%$ and $50 \%)$ doped PVDF/KI/I 2 electrolytes. The current density-voltage (J-V) curves of DSSCs with the benzoguanamine $(0 \%, 10 \%, 20 \%, 30 \%, 40 \%$ and $50 \%)$ doped $\mathrm{PVDF} / \mathrm{KI} / \mathrm{I}_{2}$ electrolytes are presented in Fig. 1.5. The photovoltaic parameters of DSSCs with benzoguanamine $(0 \%, 10 \%, 20 \%, 30 \%, 40 \%$ and $50 \%$ ) doped $\mathrm{PVDF} / \mathrm{KI} / \mathrm{I}_{2}$ electrolytes are exhibited as $\mathrm{J}_{\mathrm{sc}}=5.50 \mathrm{~mA} / \mathrm{cm}^{2}, \mathrm{~V}_{\mathrm{oc}}=0.72 \mathrm{~V}, \mathrm{FF}=0.38$ and $\eta=$ $1.5 \% ; J_{\mathrm{sc}}=6.28 \mathrm{~mA} / \mathrm{cm}^{2}, \mathrm{~V}_{\mathrm{oc}}=0.71 \mathrm{~V}, \mathrm{FF}=0.43$ and $\eta=1.9 \% ; \mathrm{J}_{\mathrm{sc}}=8.34 \mathrm{~mA} / \mathrm{cm}^{2}, \mathrm{~V}_{\mathrm{oc}}=0.69 \mathrm{~V}, \mathrm{FF}=0.49$ and $\eta=2.8 \% ; J_{\mathrm{sc}}=7.95 \mathrm{~mA} / \mathrm{cm}^{2}, V_{o c}=0.70 \mathrm{~V}, \mathrm{FF}=0.46$ and $\eta=2.5 \% ; \mathrm{J}_{\mathrm{sc}}=7.48 \mathrm{~mA} / \mathrm{cm}^{2}, V_{\text {oc }}=0.73 \mathrm{~V}, \mathrm{FF}=0.42$ and $\eta=2.3 \% ; J_{s c}=6.86 \mathrm{~mA} / \mathrm{cm}^{2}, V_{\text {oc }}=0.72 \mathrm{~V}, \mathrm{FF}=0.42$ and $\eta=2.1 \%$, respectively. The calculated 
photovoltaic parameters of DSSCs are summarized in Table 1.2. The DSSCs with the benzoguanamine $(10 \%, 20 \%, 30 \%, 40 \%$ and $50 \%)$ doped $\mathrm{PVDF} / \mathrm{KI} / \mathrm{I}_{2}$ electrolytes have higher power conversion efficiency than the DSSC with the $0 \%$ benzoguanamine doped PVDF $/ \mathrm{KI} / \mathrm{I}_{2}$ electrolyte. This is due to the electron donating capability of benzoguanamine. It has nitrogen atoms in its structure. It interacts with $\mathrm{I}_{2}$ of $\mathrm{I}_{3}{ }^{-}$to form charge transfer complex, thereby prevents the sublimation of $\mathrm{I}_{2}[8,9,13]$. Benzoguanamine decreases $\mathrm{I}_{3}{ }^{-}$concentration while it increases $\mathrm{I}^{-}$concentration $[13,15]$. Due to decrease in $\mathrm{I}_{3}$-concentration, the reaction decreases between $\mathrm{I}_{3}{ }^{-}$at $\mathrm{TiO}_{2}$ semiconductor electrolyte junction and injected electron, thereby increases the electron concentration $[13,16]$. Figure 1.6 shows the power conversion efficiency variations of DSSCs with benzoguanamine doped PVDF/KI/ $\mathrm{I}_{2}$ electrolytes. The interaction between the benzoguanamine and PVDF/KI/I $\mathrm{I}_{2}$ is shown in Fig. 1.7. The DSSC with $20 \%$ benzoguanamine doped $\mathrm{PVDF} / \mathrm{KI} / \mathrm{I}_{2}$ electrolyte has the highest power conversion efficiency. This may be due to the lowest crystallinity and the highest ionic conductivity of the $20 \%$ benzoguanamine doped $\mathrm{PVDF} / \mathrm{KI} / \mathrm{I}_{2}$ electrolyte.

$$
\begin{aligned}
& \text { Benzoguanamine }+\mathrm{I}_{3}{ }^{-} \longleftrightarrow \text { Benzoguanamine }+\mathrm{I}^{-} \\
& 2 \text { (Benzoguanamine) }+\mathrm{I}_{3}{ }^{-} \longleftrightarrow \text { (Benzoguanamine) }{ }_{2} \mathrm{I}^{+}+2 \mathrm{I}^{-}
\end{aligned}
$$

Table 1.2 The photovoltaic parameters of DSSCs with benzoguanamine (a) $0 \%$,

(b) $10 \%$, (c) $20 \%$, (d) $30 \%$, (e) $40 \%$ and (f) $50 \%$ doped PVDF/KI/ $/{ }_{2}$ electrolytes

\begin{tabular}{|llllll|}
\hline DSSC & $\begin{array}{l}\text { Benzoguanamine } \\
(\%)\end{array}$ & $J_{\text {sc }}\left(\mathrm{mA} / \mathrm{cm}^{2}\right)$ & $\mathrm{V}_{\text {oc }}(\mathrm{V})$ & FF & $\eta(\%)$ \\
\hline a & 0 & 5.50 & 0.72 & 0.38 & 1.5 \\
\hline b & 10 & 6.28 & 0.71 & 0.43 & 1.9 \\
\hline c & 20 & 8.34 & 0.69 & 0.49 & 2.8 \\
\hline d & 30 & 7.95 & 0.70 & 0.46 & 2.5 \\
\hline e & 40 & 7.48 & 0.73 & 0.42 & 2.3 \\
\hline$f$ & 50 & 6.86 & 0.72 & 0.42 & 2.1 \\
\hline
\end{tabular}

\section{Conclusions}


- In the present work, we have prepared benzoguanamine $(0 \%, 10 \%, 20 \%, 30 \%, 40 \%$ and $50 \%)$ doped $\mathrm{PVDF} / \mathrm{KI} / \mathrm{I}_{2}$ electrolytes. The prepared polymer electrolyte films were characterized by PXRD, EIS and SEM studies. The PXRD spectra have proved the lowest crystallinity for $20 \%$ benzoguanamine doped $\mathrm{PVDF} / \mathrm{KI} / \mathrm{I}_{2}$ electrolyte film. The AC-impedance spectra, revealed that the $20 \%$ benzoguanamine doped $\mathrm{PVDF} / \mathrm{KI} / \mathrm{I}_{2}$ electrolyte film has the highest ionic conductivity. The $20 \%$ benzoguanamine doped PVDF $/ \mathrm{KI} / \mathrm{I}_{2}$ electrolyte film has the smallest spherical particles with voids. The DSSCs were fabricated with the benzoguanamine $(0 \%, 10 \%, 20 \%, 30 \%, 40 \%$ and $50 \%)$ doped $\mathrm{PVDF} / \mathrm{KI} / \mathrm{I}_{2}$ electrolytes and measured the photovoltaic performance under the light intensity of $100 \mathrm{~mW} / \mathrm{cm}^{2}$. The DSSC with $20 \%$ benzoguanamine doped $\mathrm{PVDF} / \mathrm{KI} / \mathrm{I}_{2}$ electrolyte has the highest power conversion efficiency of $2.8 \%$.

\section{Declarations}

\section{Acknowledgements}

One of the authors, S. Kannadhasan, is thankful to SSN Institutions, Chennai, Tamil Nadu, India, for providing the Senior Research Fellowship.

\section{References}

1. Xia, K, Peng, Z, Hu, Z, Zhang, J, Hu, Z \& Zhu, Y 2015, 'High efficiency quasi-solid state dye-sensitized solar cells based on a novel mixed-plasticizer modified polymer electrolyte', Electrochimica Acta, vol. 153 , pp. 28-32.

2. Zhao, XG, Jin, EM \& Gu, HB 2013, 'Increased charge transfer of PVDF-HFP based electrolyte by addition of graphite nanofiber and its application in dye-sensitized solar cells', Applied surface science, vol. 287, pp. 8-12.

3. Wang, X, Zhang, Y, Xu, Q, Xu, J, Wu, B, Gong, M, Chu, J \& Xiong, S 2015, 'A low-cost quasi-solid DSSC assembled with PVDF-based gel electrolyte plasticized by PC-EC \& electrodeposited Pt counter electrode', Journal of Photochemistry and Photobiology A: Chemistry, vol. 311, pp. 112-117.

4. Kumar, KK, Ravi, M, Pavani, Y, Bhavani, S, Sharma, AK \& Rao, VN 2014, 'Investigations on $\mathrm{PEO} / \mathrm{PVP} / \mathrm{NaBr}$ complexed polymer blend electrolytes for electrochemical cell applications', Journal of Membrane Science, vol. 454, pp. 200-211.

5. Ramesh, S \& Lu, SC 2011, 'Effect of lithium salt concentration on crystallinity of poly (vinylidene fluoride-co-hexafluoropropylene)-based solid polymer electrolytes', Journal of Molecular Structure, vol. 994, no. 1, pp. 403-409.

6. Bandara, TMWJ, Dissanayake, MAKL \& Mellander, BE 2010, 'Dye sensitized solar cells with poly (acrylonitrile) based plasticized electrolyte containing Mgl2', Electrochimica acta, vol. 55, no. 6, pp. 2044-2047. 
7. Senthil, RA, Theerthagiri, J, Madhavan, J \& Arof, AK 2016, 'Influence of pyrazole on the photovoltaic performance of dye-sensitized solar cell with polyvinylidene fluoride polymer electrolytes', lonics, vol. 22, no. 3, pp. 425-433.

8. Sun, Z, Zhang, RK, Xie, HH, Liang, M, Du, RH \& Xue, S 2011, 'Influence of 4-N, Ndimethylaminopyridine on the photovoltaic performance of dye-sensitized solar cells with poly (ethyleneoxide)/oligo (ethylene glycol) blend electrolytes', Electrochimica acta, vol. 56, no. 22, pp. 7555-7562.

9. Senthil, RA, Theerthagiri, J, Madhavan, J \& Arof, AK 2016, 'Influence of pyrazole on the photovoltaic performance of dye-sensitized solar cell with polyvinylidene fluoride polymer electrolytes', lonics, vol. 22, no. 3, pp. 425-433.

10. Govindraj, M. Magesh, M. Senthil Pandian, P. Ramasamy and S. Mukhopadhyay, AIP Conf. Proc. 1731, 050111-1 (2016).

11. Senthil, RA, Theerthagiri, J \& Madhavan, J 2014, 'Optimization of performance characteristics of 2mercaptopyridine-doped polyvinylidene fluoride (PVDF) polymer electrolytes for dye-sensitized solar cells', Journal of non-crystalline solids, vol. 406, pp. 133-138.

12. Noor, MM, Careem, MA, Majid, SR \& Arof, AK 2011, 'Characterisation of plasticised PVDF-HFP polymer electrolytes', Materials Research Innovations, vol. 15(sup2), pp. s157-s160.

13. Ganesan, S, Mathew, V, Paul, BJ, Maruthamuthu, P \& Suthanthiraraj, SA 2013, 'Influence of organic nitrogenous compounds phenothiazine and diphenyl amine in poly (vinylidene fluoride) blended with poly (ethylene oxide) polymer electrolyte in dye-sensitized solar cells', Electrochimica Acta, vol. 102, pp. 219-224.

14. Senthil, RA, Theerthagiri, J \& Madhavan, J 2016, 'Organic dopant added polyvinylidene fluoride based solid polymer electrolytes for dye-sensitized solar cells', Journal of Physics and Chemistry of Solids, vol. 89, pp. 78-83.

15. Pavithra, N, Asiri, AM \& Anandan, S 2015, 'Fabrication of dye sensitized solar cell using gel polymer electrolytes consisting poly (ethylene oxide)-acetamide composite', Journal of Power Sources, vol. 286, pp. 346-353.

16. Kusama, H, Kurashige, MK, Arakawa, H 2005, 'Influence of nitrogen-containing heterocyclic additives in $\mathrm{I}^{-} / \mathrm{I}_{3}{ }^{-}$redox electrolytic solution on the performance of Ru-dye-sensitized nanocrystalline $\mathrm{TiO}_{2}$ solar cell', Journal of Photochemistry and Photobiology A, Vol. 169, pp. 169-176.

\section{Figures}




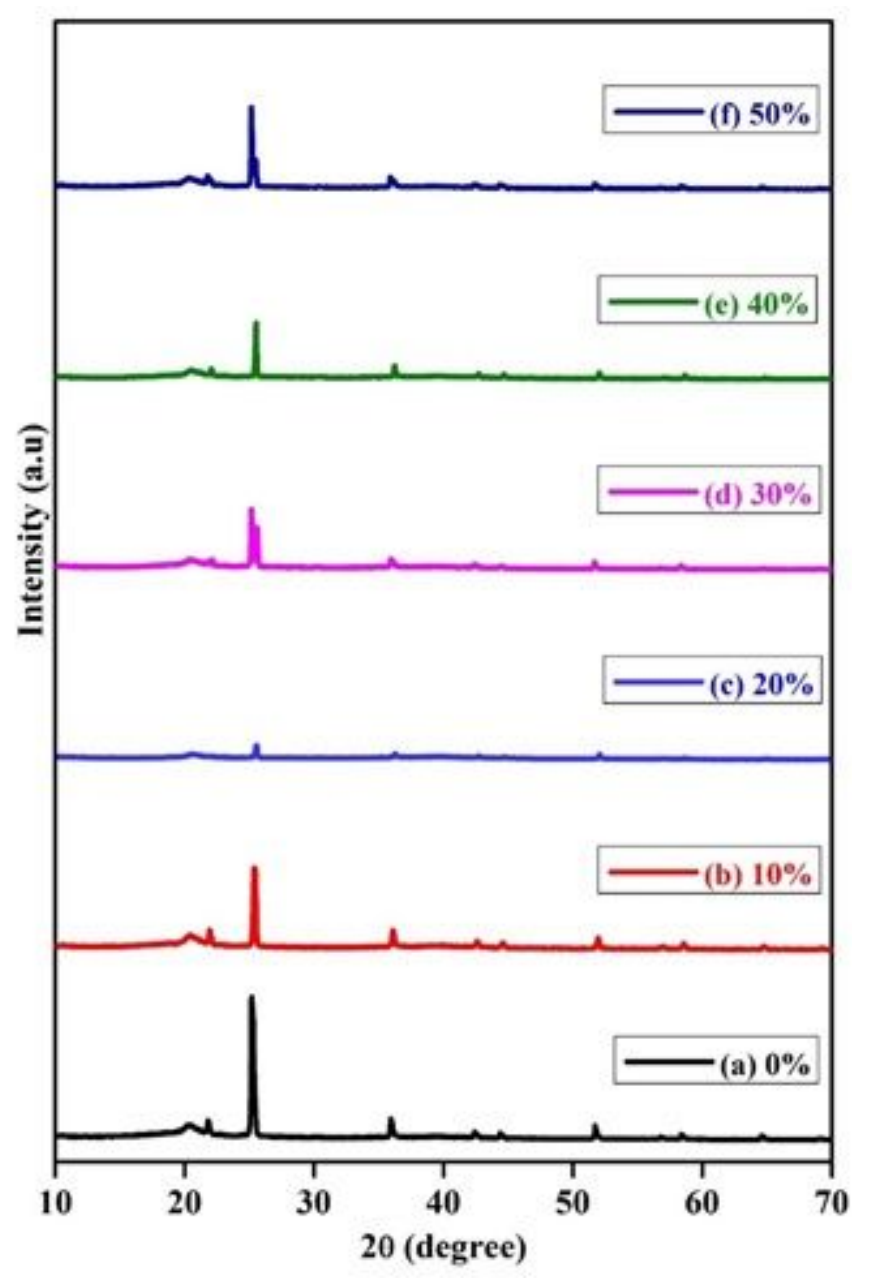

Figure 1

PXRD patterns of benzoguanamine (a) $0 \%$, (b) $10 \%$, (c) $20 \%$, (d) $30 \%$, (e) $40 \%$ and (f) $50 \%$ doped PVDF/KI/I2 electrolyte films 

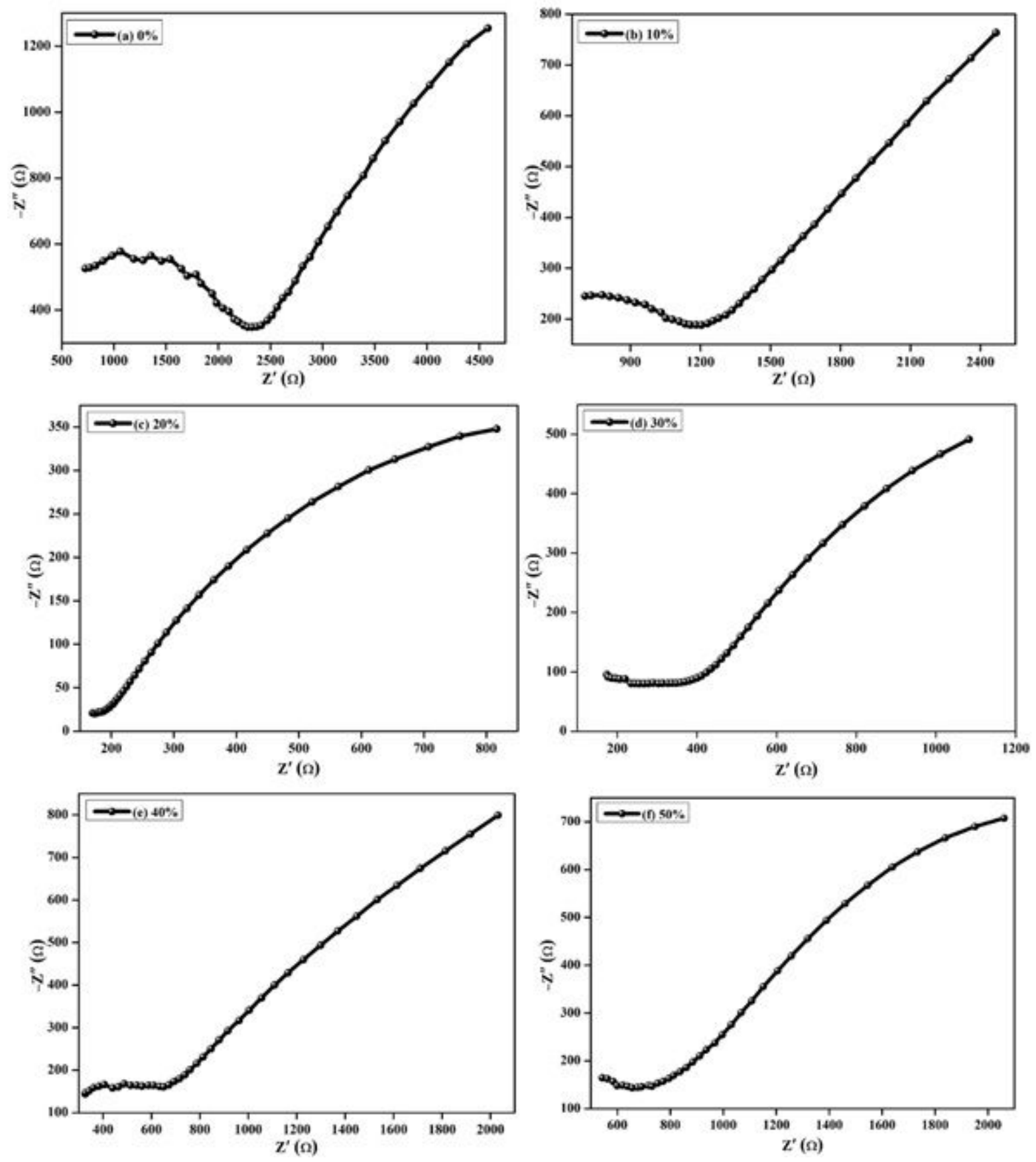

Figure 2

AC-impedance spectra of benzoguanamine (a) $0 \%$, (b) $10 \%$, (c) $20 \%$, (d) $30 \%$, (e) $40 \%$ and (f) $50 \%$ doped PVDF/KI/I2 electrolyte films 


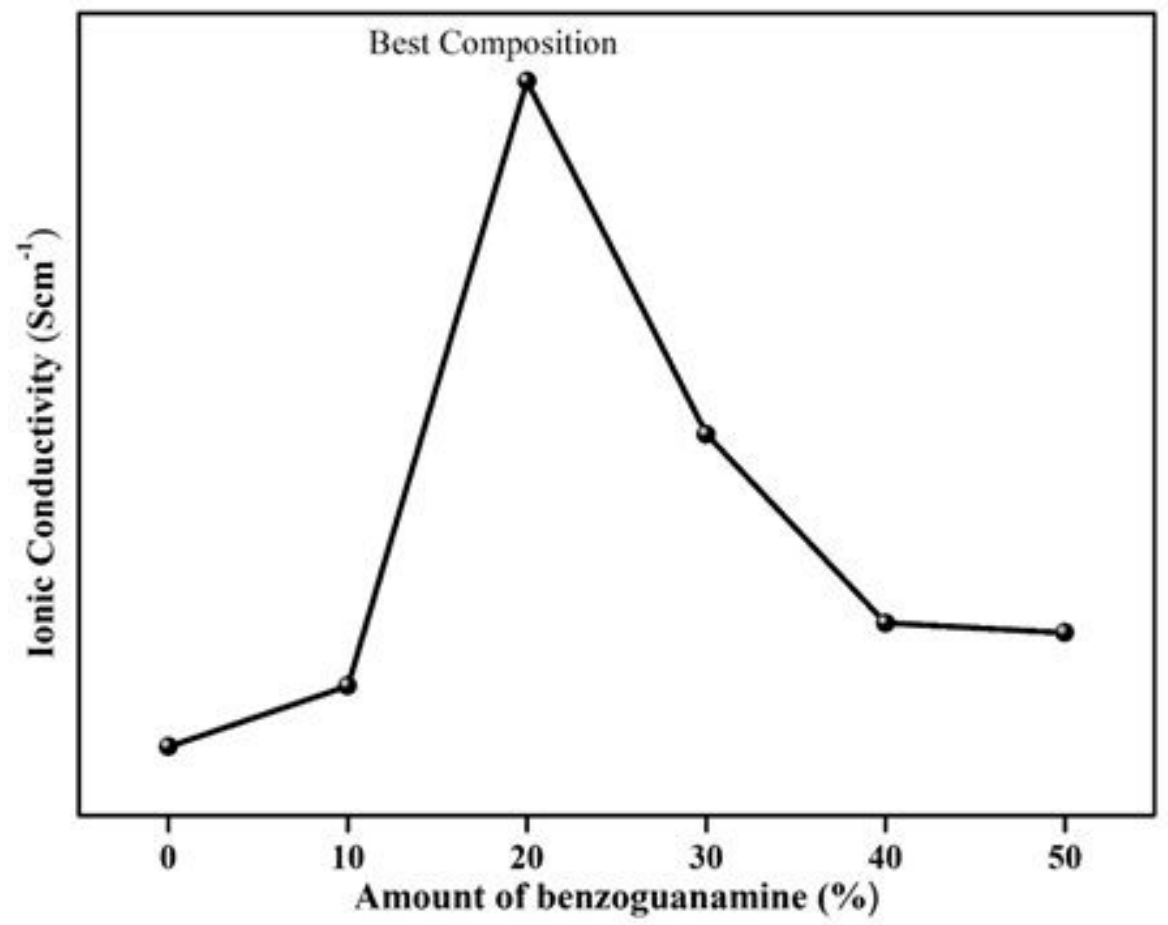

Figure 3

Conductivity variations of benzoguanamine doped PVDF/KI/I2 electrolyte films 


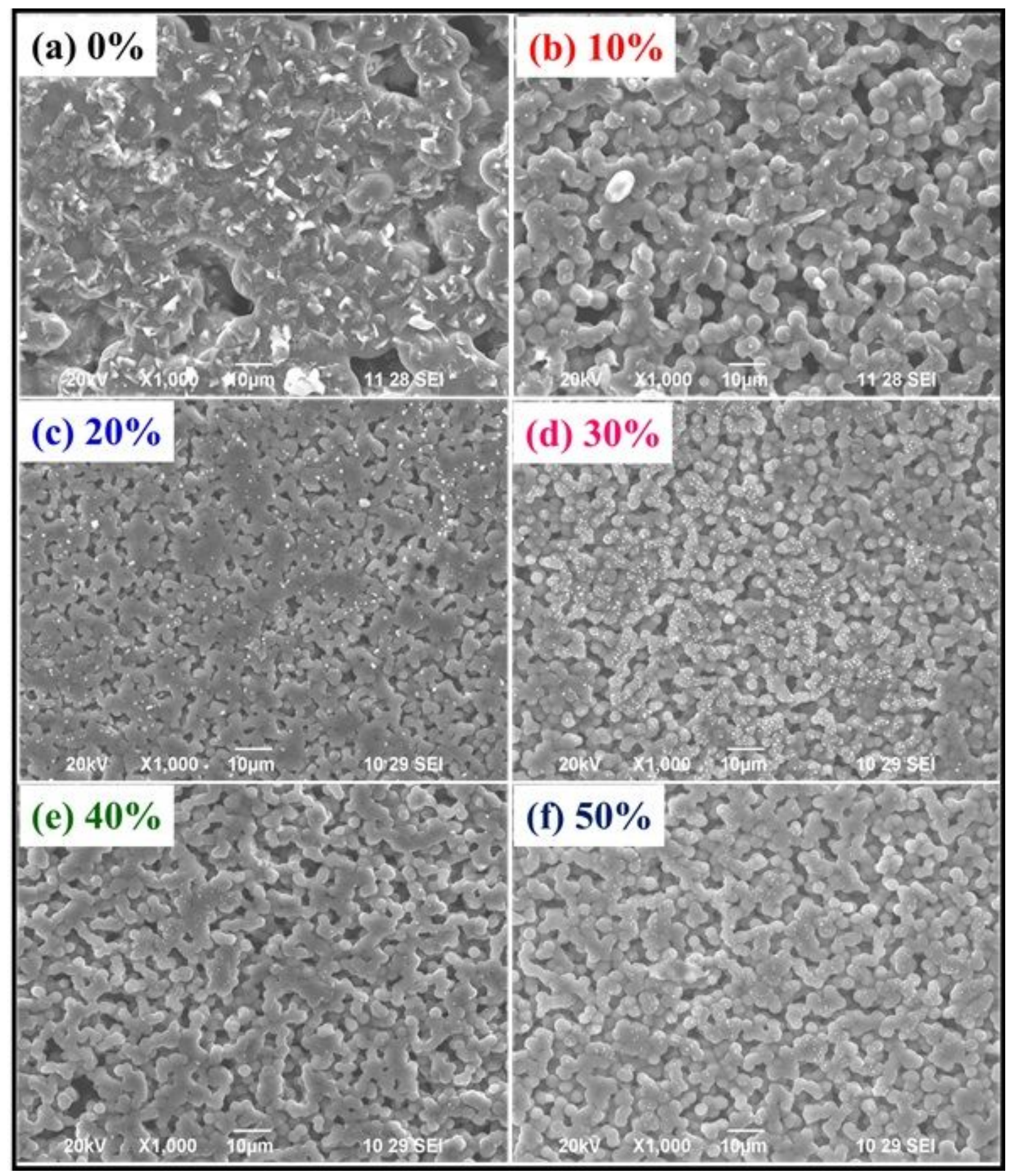

Figure 4

SEM images of benzoguanamine (a) 0\%, (b) 10\%, (c) 20\%, (d) 30\%, (e) $40 \%$ and (f) $50 \%$ doped $\mathrm{PVDF} / \mathrm{KI} / \mathrm{I} 2$ electrolyte films 


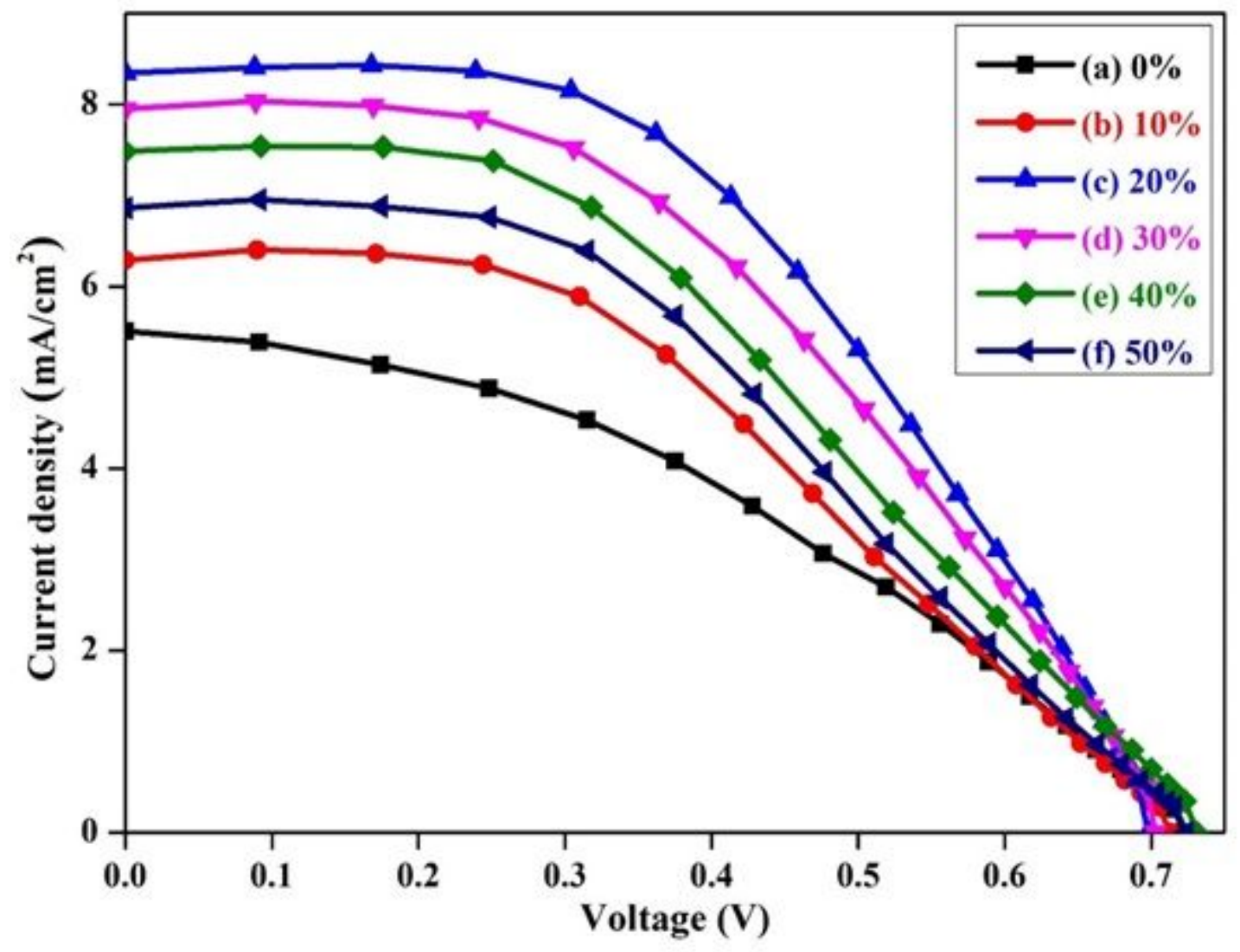

Figure 5

The photovoltaic (J-V) curves of DSSCs with benzoguanamine (a) $0 \%$, (b) $10 \%$, (c) $20 \%$, (d) $30 \%$, (e) $40 \%$ and (f) $50 \%$ doped PVDF/KI/I2 electrolytes

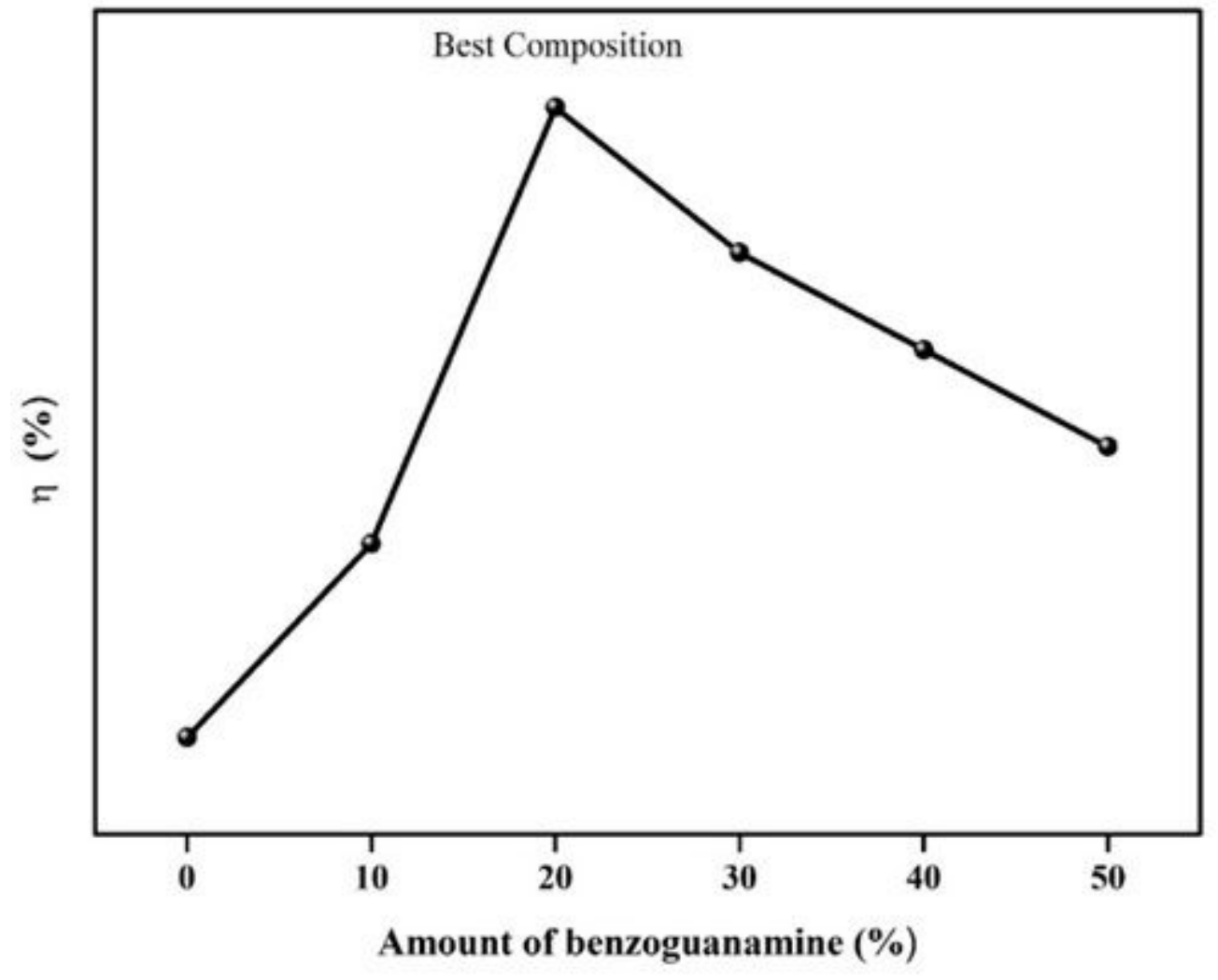


Figure 6

Efficiency variations of DSSCs with benzoguanamine doped PVDF/KI/I2 electrolytes

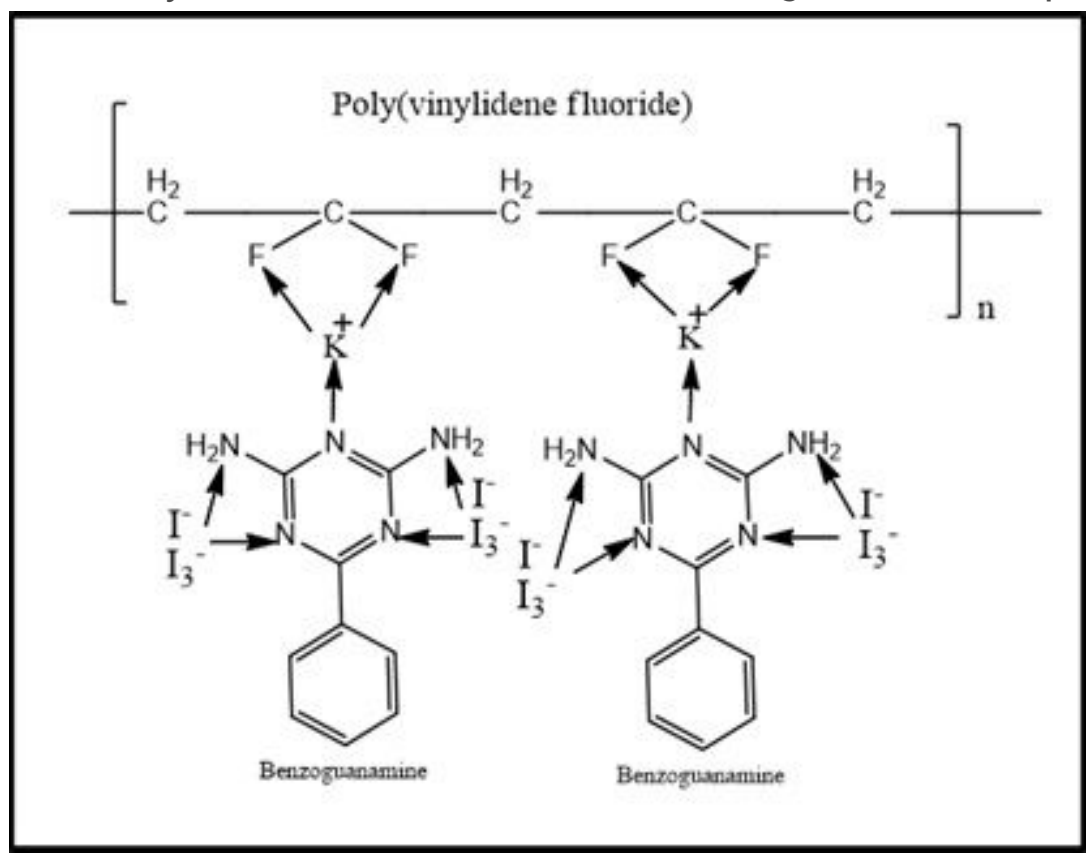

Figure 7

Molecular interaction of benzoguanamine with $\mathrm{PVDF} / \mathrm{KI} / \mathrm{I2}$ 